\title{
Zinc Finger FYVE Domain-Containing Protein 19
}

National Cancer Institute

\section{Source}

National Cancer Institute. Zinc Finger FYVE Domain-Containing Protein 19. NCI

Thesaurus. Code C97225.

Zinc finger FYVE domain-containing protein 19 (471 aa, $\sim 52 \mathrm{kDa}$ ) is encoded by the human ZFYVE19 gene. This protein may be involved in the cellular response to DNA damage. 